\title{
Genetic diversity in Guazuma crinita from eleven provenances in the Peruvian Amazon revealed by ISSR markers
}

\author{
Diversidad genética de Guazuma crinita en once procedencias \\ de la Amazonía Peruana revelada por marcadores ISSR
}

\author{
Lady Laura Tuisima Coral a, Petra Hlásná Čepková a*, Bohdan Lojka a , John C Weber b, \\ Serafín Filomeno Alves-Milho ${ }^{\mathrm{c}}$ \\ *Corresponding authos: ${ }^{a}$ Czech University of Life Sciences Prague, Faculty of Tropical AgriSciences, Kamýcká 129, 165 21, \\ Prague 6-Suchdol, Czech Republic, phone+420 224382 182, cepkova@ftz.czu.cz, petrahlasna@gmail.com \\ ${ }^{\mathrm{b}}$ World Agroforestry Centre, Lima, Peru. \\ c Peruvian Amazon Research Institute (IIAP), Programa Pro Bosques,CFB km 12.4 Margen derecho, Pucallpa, Peru.
}

\begin{abstract}
SUMMARY
Guazuma crinita is an important fast-growing timber tree species widely used in agroforestry systems in the Peruvian Amazon. The objectives of our research were (i) to assess genetic diversity of G. crinita using inter-simple sequence repeat (ISSR) markers and (ii) estimate correlation between genetic and geographic distances among provenances. The sample included 44 genotypes from 11 provenances in the Aguaytia and neighboring Pachitea watersheds in the Peruvian Amazon. Ten ISSR primers amplified a total of 65 bands of which 61 were polymorphic (93.8 \%). The range of DNA amplification varied from 260 to 2,200 bp. Among the provenances, Macuya exhibited the highest percentage of polymorphic bands (PPB) with 67.7 \%, 0.21 Nei's gene diversity $(\mathrm{He})$ and 0.33 Shannon index $(I)$. Overall genetic differentiation $\left(G_{s t}\right)$ was 0.03 , indicating $97 \%$ of genetic diversity within provenances. Gene flow $(\mathrm{Nm})$ was 12.9 alleles per generation. Cluster analysis was not related to geographic origin, suggesting a common gene pool. However a weak positive correlation $(\mathrm{r}=0.27, P<0.05)$ was found between genetic and geographic distance. This is the first study of genetic diversity and structure of G. crinita. We recommend in situ conservation strategies for populations with high levels of genetic diversity.
\end{abstract}

Key words: inter-simple sequence repeat markers, genetic diversity, genetic distance, gene flow, geographic distance.

\section{RESUMEN}

Guazuma crinita es una importante especie maderable de rápido crecimiento ampliamente usada en sistemas agroforestales en la Amazonía Peruana. Los objetivos de nuestra investigación fueron; (i) evaluar la diversidad genética de G. crinita revelada por marcadores de intersecuencias simples repetidas (ISSR) además de (ii) estimar la correlación entre las distancias genéticas y geográficas entre procedencias. La muestra incluyó 44 genotipos de 11 procedencias en las cuencas de Aguaytía y Pachitea en la Amazonía Peruana. Diez cebadores ISSR amplificaron un total de 65 bandas de las cuales 61 fueron polimórficas (93,8 \%). El rango de amplificaciones de ADN varió desde 260 hasta 2.200 bp. Entre las procedencias, Macuya exhibió el mayor porcentaje de bandas polimórficas (PPB) con 67,7 \%, 0,21 diversidad genética de $\mathrm{Nei}(\mathrm{He})$ y 0,33 de índice de Shannon $(\mathrm{I})$. La diferenciación genética general $\left(G_{s t}\right)$ fue 0,03 , indicando $97 \%$ de la variación genética dentro de las procedencias. El flujo genético $(\mathrm{Nm})$ fue 12,9 alelos por generación. El análisis de agrupamiento no estuvo relacionado con el origen geográfico sugiriendo una fuente genética en común. Sin embargo, se encontró una correlación positiva débil $(\mathrm{r}=0,27, P<0,05)$ entre las distancias genéticas y geográficas. Este es el primer estudio sobre la diversidad y estructura genética de G. crinita. Se recomiendan estrategias de conservación in situ para las poblaciones con altos niveles de diversidad genética.

Palabras clave: marcadores Inter-simple sequence repeat, diversidad genética, distancia genética, flujo genético, distancia geográfica.

\section{INTRODUCTION}

A domestication program for tropical tree species started in the mid-90s in the Peruvian Amazon, and identified Guazuma crinita Mart. (Sterculiaceae family) as one of the priority timber species for agroforestry systems (Sotelo-Montes and Weber 1997). This pioneer species can be inter-cultivated with food crops because it has a small crown with thin branches, and the older branches naturally self-prune in the lower crown. It provides wood products at an early age (8-10 years), can be coppiced for successive harvests and contributes significantly to farmers' income (Labarta and Weber 1998). Due to its fast initial height growth (up to $3 \mathrm{~m}$ per year) it has also been promoted in reforestation programs and agroforestry systems (IIAP 2009). It naturally colonizes the floodplain and disturbed 
secondary forests in the lowland jungle (below 1,000 m elevation) in the Amazonian basin of Peru, Ecuador, and Brazil (Encarnación 1983).

The mating system of $G$. crinita has not been studied yet, though since most tropical trees are predominantly out-crossing, the same is assumed for this species (Muchugi et al. 2008). Trees can begin flowering after 2-3 years and produce millions of seeds that are dispersed by both wind and water at the beginning of the rainy season (Rochon et al. 2007). The species can potentially produce a dense stand of natural regeneration in open patches (Rochon et al. 2007). Its importance has prompted research to identify the best provenances and improve the management of the species.

In general, very little research on intra-specific genetic variation in agroforestry tree species in the tropics has been reported (Weber and Sotelo-Montes 2008). Genetic variability is essential to the success of strategies for tree improvement including selection, sustainable management and genetic resource conservation (O'Neill et al. 2001).

Morphological characters and commercial wood traits have been used traditionally to characterize levels and patterns of diversity; however these traits alone represent only a small portion of the plant genome and are also influenced by environmental factors (Muchugi et al. 2008). The use of genetic markers based on DNA overcome these disadvantages and are able to measure the genetic diversity in plant species (White et al. 2007). Inter Simple Sequence Repeat (ISSR) markers combine some advantages of other markers such as reproducibility, low costs and no need to develop species-specific primers for analysis. ISSRs are an efficient tool to analyze the variability and genetic structure in natural, managed and cultivated tree stands, and are useful to identify genotypes, even among highly related individuals (Thangjam 2014).

The objectives of this research are (i) to assess genetic diversity of G. crinita revealed by ISSR markers and (ii) to estimate the correlation between genetic and geographic distances among provenances. We hypothesized that there is a high level of polymorphism within provenances, very little differentiation among provenances and a positive relationship between genetic distance and geographic distance among provenances.

\section{METHODS}

Sample origin and plant material. We analyzed 44 genotypes of $G$. crinita that were vegetatively propagated from a provenance/progeny test of 11 provenances collected from the Aguaytia and neighboring Pachitea river watersheds (table 1, figure 1). They were identified and selected based on phenotypic measurements along ten years of evaluation. These genotypes were established in a clonal multiplication garden at the Peruvian Amazon Research Institute (IIAP), located $12.4 \mathrm{~km}$ from Pucallpa in the Ucayali Region. Young leaf tissue samples of each genotype were individually collected and stored in micro-test tubes with silica gel for further DNA isolation.

DNA isolation and ISSR amplification. The DNA from leaf samples was extracted using the CTAB (cetyltrimethylammonium bromide) method (Doyle and Doyle 1987). DNA quality was determined by $0.8 \%$ agarose gel electrophoresis and using a Nanodrop Spectrophotometer (Thermo Scientific USA). The final concentration of all DNA samples was adjusted to $50 \mathrm{ng} \mu \mathrm{L}^{-1}$ for PCR (polymerase chain reaction),

Table 1. Original 11 provenances from the Aguaytia (A) and Pachitea (P) river watersheds in the Peruvian Amazon.

Once procedencias originales de las cuencas de los rios Aguaytía (A) y Pachitea (P) en la Amazonia Peruana.

\begin{tabular}{|c|c|c|c|c|}
\hline \multirow[t]{2}{*}{ Provenance } & \multirow{2}{*}{$\begin{array}{l}\text { Altitude } \\
\text { (m) }\end{array}$} & \multirow[t]{2}{*}{ No. of samples (code) } & \multicolumn{2}{|c|}{$\begin{array}{l}\text { UTM Coordinates } \\
\text { (Zone 18) }\end{array}$} \\
\hline & & & East & North \\
\hline Nueva Requena (ANR) & 150 & $5($ ANR07, 08, 11, 12, 13) & 518637 & 9095053 \\
\hline Neshuya-stream (ANS) & 180 & $4(\mathrm{ANS} 8,09,10,12)$ & 499925 & 9060461 \\
\hline Tahuayo-stream (ATS) & 175 & 3 (ATS01, 02,09) & 501915 & 9062422 \\
\hline Curimana-river (ACR) & 170 & $4(\mathrm{ACR} 14,16,17,20)$ & 491115 & 9074726 \\
\hline Aguaytia-river (AAR) & 280 & $2($ AAR01,13) & 461057 & 9025361 \\
\hline Von Humboldt (AVH) & 220 & $2(\mathrm{AVH} 01,11)$ & 490269 & 9023779 \\
\hline San Alejandro (ASA) & 230 & $5(\mathrm{ASA} 1,10,11,14,15)$ & 486156 & 9021267 \\
\hline Curimana (ACU) & 185 & 4 (ACU03, 04, 06, 07) & 504815 & 9049743 \\
\hline Tournavista-road (ATR) & 195 & 2 (ATR01, 04) & 497745 & 9035717 \\
\hline Puerto Inca (PPI) & 290 & 3 (PPI01, 03, 13) & 503328 & 8958727 \\
\hline Macuya (PMA) & 260 & 10 (PMA01, 11, 16, 23, 24, 33, 36,42, 44, 46) & 498323 & 8978543 \\
\hline
\end{tabular}




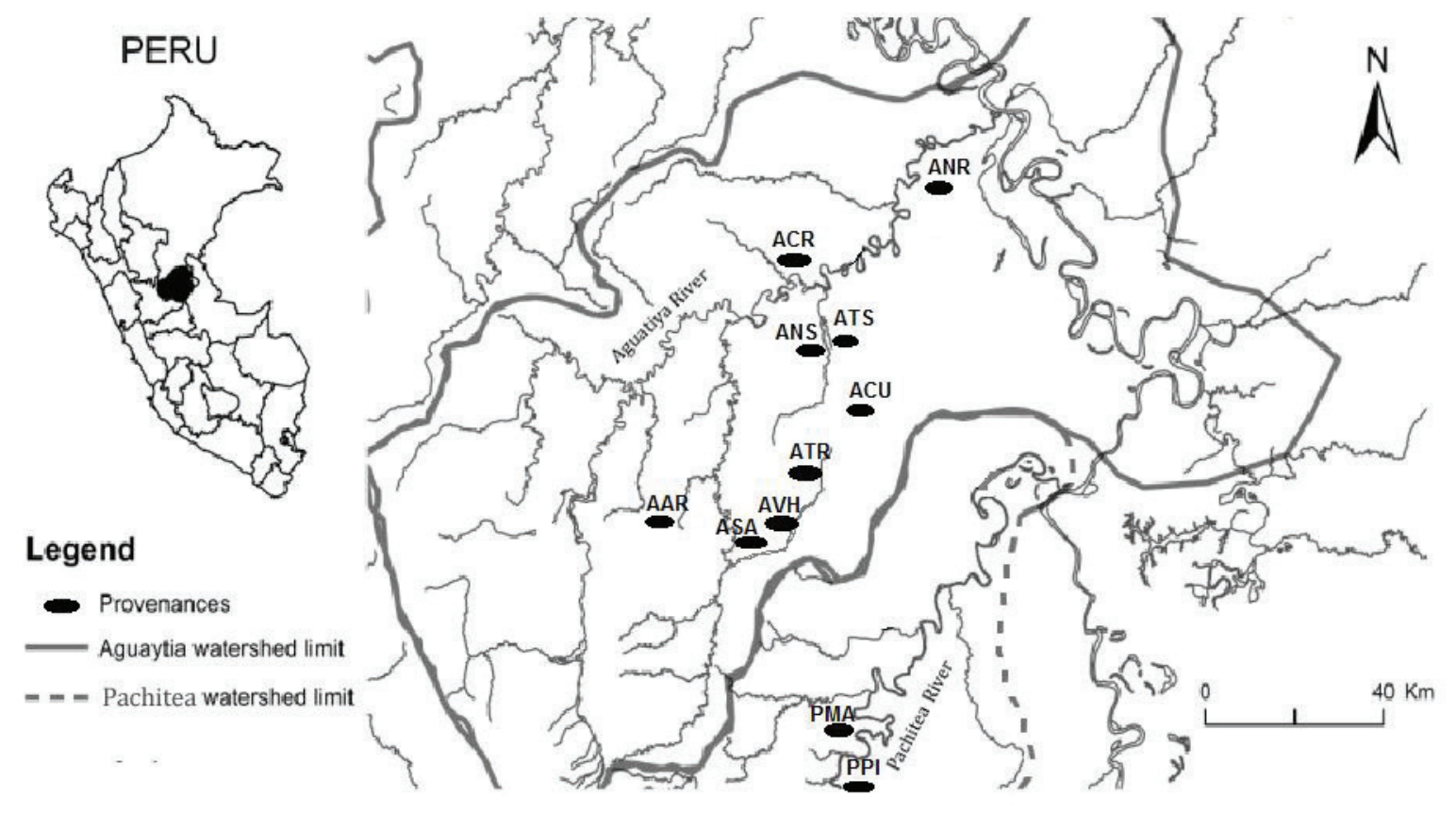

Figure 1. Map of collection areas of 11 provenances that were sampled in the study. ANR: Nueva Requena, ANS: Neshuya-stream, ATS: Tahuayo-stream, ACR: Curimana-river, AAR: Aguaytia-river, AVH: Von Humboldt, ASA: San Alejandro, ACU: Curimana, ATR: Tournavista-road, PPI: Puerto Inca, PMA: Macuya.

Mapa de las áreas de colección de 11 prodecencias que fueron muestreadas en el estudio. ANR: Nueva Requena, ANS: Neshuya-stream, ATS: Tahuayo-stream, ACR: Curimana-river, AAR: Aguaytia-river, AVH: Von Humboldt, ASA: San Alejandro, ACU: Curimana, ATR: Tournavistaroad, PPI: Puerto Inca and PMA: Macuya.

and stored at $-20{ }^{\circ} \mathrm{C}$. Among the 30 universal UBC-ISSR primers (University of British Columbia, Canada) tested for their ability to produce distinct, reproducible and well-resolved fragments in the 44 individual genotypes, 10 primers were selected for the amplification of all the samples (table 2). The PCR amplification was performed using $\mathrm{T} 100^{\mathrm{TM}}$ thermal Cycler (Bio-Rad Laboratories, USA). Each $20 \mu \mathrm{L}$ PCR reaction mixture was composed by $10 \mu \mathrm{L}$ of $2 \mathrm{x}$ PPP Master Mix [ $150 \mathrm{mM}$ Tris- $\mathrm{HCl}, \mathrm{pH} 8.8\left(25^{\circ} \mathrm{C}\right), 40 \mathrm{mM}$ $\left(\mathrm{NH}_{4}\right)_{2} \mathrm{SO}_{4}, 0.02 \%$ Tween $20,5 \mathrm{mM} \mathrm{MgCl} 2,400 \mu \mathrm{M} \mathrm{dATP}$, $400 \mu \mathrm{M}$ dCTP, $400 \mu \mathrm{M}$ dGTP, $400 \mu \mathrm{M}$ dTTP, $100 \mathrm{U} \mathrm{mL}^{-1}$ Taq-Purple DNA polymerase, monoclonal antibody antiTaq (38 nM), stabilizers and additives] (Tob-Bio, Czech Republic), $10 \mu \mathrm{M}$ of respective ISSR primer, $2 \mu \mathrm{L}$ of DNA elution, $0.2 \mu \mathrm{L}$ of BSA (Thermoscientific, Lithuania) and $7.3 \mu \mathrm{L}$ PCR $\mathrm{H}_{2} \mathrm{O}$ (Top-Bio, Czech Republic).

The cycling conditions were as follows: initial denaturation for four minutes at $94{ }^{\circ} \mathrm{C}, 45$ cycles of denaturation for 30 seconds at $94{ }^{\circ} \mathrm{C}$, primer annealing at $47-52^{\circ} \mathrm{C}$ for 45 seconds at specific annealing temperature for each primer, extension for two minutes at $72{ }^{\circ} \mathrm{C}$ and a final 10 minute extension at $72{ }^{\circ} \mathrm{C}$. Amplified products were analyzed through electrophoresis on $2 \%$ agarose gel in $1 \mathrm{x}$ TBE buffer, 60 volts, 120 amperes for 180 minutes and detected by ethidium bromide staining (Carl Roth GmbH, Germany). The bands were observed under UV light (Cleaver Scientific, UK). The size of the amplified products was estimated using Thermo Scientific Gene Ruler 100 bp Plus DNA Ladder (Thermoscientific, Lithuania). PCR amplification of the samples with each primer was carried out in duplicate so as to ensure the consistency and reproducibility of the results.

Data analyses. ISSR fragments were scored as presence (1) or absence (0) of bands in the gel profile. Only strong bands were used to construct a binary matrix. The data were used to calculate percentage of polymorphic bands, Shannon's information index (I, LogBase L' e), Nei's genetic distance matrix, gene diversity $(\mathrm{He})$, genetic differentiation $\left(G_{\mathrm{s}}\right)$ and gene flow $(\mathrm{Nm})$ among provenances using POPGENE V1.32 (Yeh et al. 1997). A dendrogram was constructed by unweighted neighbor joining based on Jaccard's dissimilarity index. This analysis was performed using the DARwin5 software (Perrier and JacquemoudCollet 2006). Mantel test in Gen Al Ex V6 (Peakall and Smouse 2012) was performed using Nei's unbiased genetic distances matrix and the matrix of geographic distances to determine whether the geographical and genetic distances between provenances were correlated. 
Table 2. Primers used in the ISSR analysis and summary of amplifications.

Cebadores utilizados en el análisis de ISSR y resumen de amplificaciones.

\begin{tabular}{ccccccccc}
\hline No. & Primers & $\begin{array}{c}\text { Sequence } \\
\left(5^{\prime}-3^{\prime}\right)^{\mathrm{a}}\end{array}$ & $\begin{array}{c}\text { Annealing } \\
\text { temperature }\left({ }^{\circ} \mathrm{C}\right)\end{array}$ & $\begin{array}{c}\text { Total } \\
\text { bands }\end{array}$ & $\begin{array}{c}\text { Polymorphic } \\
\text { bands }\end{array}$ & $\begin{array}{c}\text { Unique } \\
\text { bands }\end{array}$ & $\begin{array}{c}\text { PPB }^{\mathrm{b}} \\
(\%)\end{array}$ & $\begin{array}{c}\text { Size of bands } \\
(\mathrm{pb})\end{array}$ \\
\hline 1 & $\mathrm{UBC} 807$ & $(\mathrm{AG})_{8} \mathrm{~T}$ & 48 & 236 & 10 & 10 & 15.4 & $340-1,700$ \\
2 & $\mathrm{UBC} 809$ & $(\mathrm{AG})_{8} \mathrm{G}$ & 49 & 217 & 7 & 6 & 9.2 & $420-1,300$ \\
3 & $\mathrm{UBC} 810$ & $(\mathrm{GA})_{8} \mathrm{~T}$ & 49 & 211 & 5 & 5 & 7.7 & $520-1,300$ \\
4 & $\mathrm{UBC} 812$ & $(\mathrm{GA})_{8} \mathrm{~A}$ & 49 & 164 & 6 & 6 & 9.2 & $425-1,600$ \\
5 & $\mathrm{UBC} 814$ & $(\mathrm{CT})_{8} \mathrm{~A}$ & 48 & 115 & 9 & 9 & 13.9 & $490-2,200$ \\
6 & $\mathrm{UBC} 828$ & $(\mathrm{TG})_{8} \mathrm{~A}$ & 52 & 126 & 8 & 8 & 12.3 & $480-2,000$ \\
7 & $\mathrm{UBC} 834$ & $(\mathrm{AG})_{8} \mathrm{YT}$ & 48 & 45 & 1 & 0 & 0.0 & 850 \\
8 & $\mathrm{UBC} 841$ & $(\mathrm{GA})_{8} \mathrm{YC}$ & 49 & 282 & 11 & 11 & 16.9 & $260-1,250$ \\
9 & $\mathrm{UBC} 848$ & $(\mathrm{CA})_{8} \mathrm{RG}$ & 47 & 166 & 6 & 6 & 9.2 & $340-1,300$ \\
10 & $\mathrm{UBC} 866$ & $(\mathrm{CTC})_{6}$ & 47 & 90 & 2 & 0 & 0.0 & $1,020-1,490$ \\
Total & & & & 1,652 & 65 & 61 & 93.8 & \\
\hline
\end{tabular}

a Single letter abbreviations for mixed-base positions: $Y=(C, T), R=(A, G)$.

${ }^{\mathrm{b}} \mathrm{PPB}=$ percentage of polymorphic bands.

\section{RESULTS}

Genetic diversity. The DNA amplified using ISSR markers generated a total number of 65 fragments by the ten primers; the amplified fragments were within a range of 260 to $2,200 \mathrm{bp}$. The total number of fragments amplified per primer ranged from 1 (UBC 834) to 11 (UBC 841). A total of 61 fragments were polymorphic (93.8\%) (table 2).

The average numbers of loci and polymorphic loci generated per primer were 6.5 and 6.1 , respectively. The overall analyses of genetic variation at watershed and provenance level are shown in table 3. The percentage of polymorphic bands was higher in Aguaytia watershed, while Nei's gene diversity $(\mathrm{He})$ and Shannon index $(I)$ were higher in the Pachitea watershed. Among the provenances, the percentage of polymorphic bands was the highest in Macuya (PMA) and the lowest in Tournavista-road (ATR). Tournavista-road also had the lowest Nei's gene diversity $(\mathrm{He})$ and Shannon index $(I)$.

Population genetic structure. Overall coefficient of genetic differentiation $\left(G_{s t}\right)$ was 0.03 , which indicates that $3 \%$ of the genetic variability was distributed among provenances. Gene flow $(\mathrm{Nm})$ was estimated to be 12.9 migrants per generation contributing alleles between provenances. An analysis of Nei's genetic identities of the pair-wise comparison between provenances varied from 0.84 to 0.96 . Genetic distances among provenances ranged from 0.025 to 0.155 with a mean of 0.061 (table 4). The lowest genetic distance was between Nueva Requena (ANR) and Curimana river (ACR) provenances which are both located along the Curimana river (figure 1), suggesting that downstream dispersal of seeds reduces the genetic distance. Puerto Inca (PPI) from the Pachitea watershed and Aguaytia river (AAR) from the Aguaytia watershed had the highest genetic distance (0.155), suggesting that genetic distance was higher between provenances from different watersheds. However, the genetic distance was relatively low between most provenances in the Aguaytia watershed and Macuya, which is in the Pachitea watershed (figure 1). It may reflect the exchange of genes by the influence of human activity along closer watersheds.

In order to assess relationships among provenances, a cluster analysis was used to generate a dendrogram based on Jaccard's dissimilarity among the 44 genotypes (figure 2). The dendrogram showed that the genotypes were grouped into three distinct clusters. The first cluster included 22 genotypes [five from the PMA and ASA provenances (PMA24, PMA23, PMA44, PMA11, PMA36, ASA11, ASA10, ASA14, ASA01 and ASA15), two from PPI, ATS, ACU and ANR provenances (PPI01, PPI13, ATS09, ATS01, ACU07, ACU06, ANR13 and ANR07), one from ACR, AAR, ANS and AVH provenances (ACR16, AAR01, ANS12 and AVH01)]. The second cluster included 21 genotypes [five from PMA provenance (PMA16, PMA46, PMA42, PMA33 and PMA01), three from ANR and ACR provenances (ANR08, ANR12, ANR11, ACR17, ACR20 and ACR14), two from ANS, ATR and ACU provenances (ANS08, ANS10, ATR04, ATR01, ACU03 and ACU04), and one from PPI, AAR, AVH, and ATS provenances (PPI03, AAR13, AVH11 and ATS02)]. The third cluster included only one genotype from ANS provenance 
Table 3. Analysis of genetic variation generated by ISSR markers in Guazuma crinita provenances/watershed from 44 genotypes. Análisis de variación genética generado por marcadores ISSR en procedencias/cuencas de 44 genotipos de Guazuma crinita.

\begin{tabular}{lccc}
\hline \multicolumn{1}{c}{ Provenances/Watersheds } & Percentage of polymorphic bands (PPB) & Nei's gene diversity $(\mathrm{He})$ & Shannon index $(I)$ \\
\hline Nueva Requena (ANR) & 41.5 & 0.15 & 0.22 \\
Neshuya - stream (ANS) & 30.8 & 0.13 & 0.19 \\
Tahuayo - stream (ATS) & 47.7 & 0.21 & 0.30 \\
Curimana - river (ACR) & 40.0 & 0.16 & 0.23 \\
Aguaytia - river (AAR) & 24.6 & 0.12 & 0.17 \\
Von Humboldt (AVH) & 18.0 & 0.09 & 0.13 \\
San Alejandro (ASA) & 47.7 & 0.19 & 0.28 \\
Curimana (ACU) & 56.9 & 0.23 & 0.34 \\
Tournavista - road (ATR) & 6.15 & 0.03 & 0.04 \\
Puerto Inca (PPI) & 52.3 & 0.20 & 0.30 \\
Macuya (PMA) & 67.7 & 0.24 & 0.35 \\
Aguaytia watershed (A) & 83.1 & 0.20 & 0.33 \\
Pachitea watershed (P) & 78.5 & 0.24 & 0.37 \\
Average (prov. level) & 39.4 & 0.16 & 0.23 \\
Species level & 93.8 & 0.22 & 0.36 \\
\hline
\end{tabular}

Table 4. Nei's genetic distance and geographic distance among the provenances of G. crinita.

Distancias genéticas de Nei y distancias geográficas entre procedencias de G. crinita.

\begin{tabular}{cccccccccccc}
\hline & ANR & ANS & ATS & ACR & AAR & PPI & AVH & PMA & ASA & ACU & ATR \\
\hline ANR & $* * *$ & 39.3 & 36.7 & 34.2 & 90.4 & 137.2 & 76.7 & 118.3 & 80.6 & 47.4 & 62.9 \\
ANS & 0.037 & $* * *$ & 2.8 & 16.8 & 52.4 & 101.8 & 37.9 & 81.9 & 41.5 & 11.8 & 24.8 \\
ATS & 0.068 & 0.065 & $* * *$ & 16.4 & 55.2 & 103.7 & 40.4 & 84.0 & 44.1 & 13.0 & 27.0 \\
ACR & 0.025 & 0.036 & 0.068 & $* * *$ & 57.8 & 116.6 & 51.0 & 96.5 & 53.7 & 28.5 & 39.6 \\
AAR & 0.081 & 0.099 & 0.112 & 0.086 & $* * *$ & 78.9 & 29.3 & 59.8 & 25.4 & 50.1 & 38.1 \\
PPI & 0.135 & 0.114 & 0.090 & 0.106 & 0.155 & $* * *$ & 66.4 & 20.4 & 64.9 & 91.0 & 77.2 \\
AVH & 0.053 & 0.042 & 0.122 & 0.047 & 0.109 & 0.151 & $* * *$ & 45.9 & 4.8 & 29.8 & 14.1 \\
PMA & 0.029 & 0.036 & 0.058 & 0.033 & 0.081 & 0.081 & 0.043 & $* * *$ & 44.4 & 71.5 & 57.2 \\
ASA & 0.063 & 0.058 & 0.063 & 0.057 & 0.077 & 0.087 & 0.071 & 0.037 & $* * *$ & 34.0 & 18.5 \\
ACU & 0.039 & 0.048 & 0.070 & 0.055 & 0.106 & 0.138 & 0.083 & 0.044 & 0.058 & $* * *$ & 15.7 \\
ATR & 0.046 & 0.039 & 0.095 & 0.052 & 0.104 & 0.148 & 0.067 & 0.057 & 0.089 & 0.076 & $* * *$ \\
\hline
\end{tabular}

Geographic distance in kilometers above diagonal and Nei's genetic distance below diagonal. See table 1 for provenance abbreviations.

(ANS09). Topology of the dendrogram showed that clusters were not related to the geographic origins of the genotypes.

There was a weak positive relationship $(\mathrm{r}=0.27, P<$ $0.05)$ between genetic and geographic distance for the 11 provenances based on the Mantel test. This suggests that geographic distance had a small effect on genetic differentiation among provenances.

\section{DISCUSSION}

Tree domestication has evolved over the last two decades to become an important global program, and molecular techniques have been used to analyze genetic diversity in several agroforestry tree species (Leakey et al. 2012). A number of authors have examined both natural stands of tropical trees and cultivated samples (e.g. Hollingsworth 


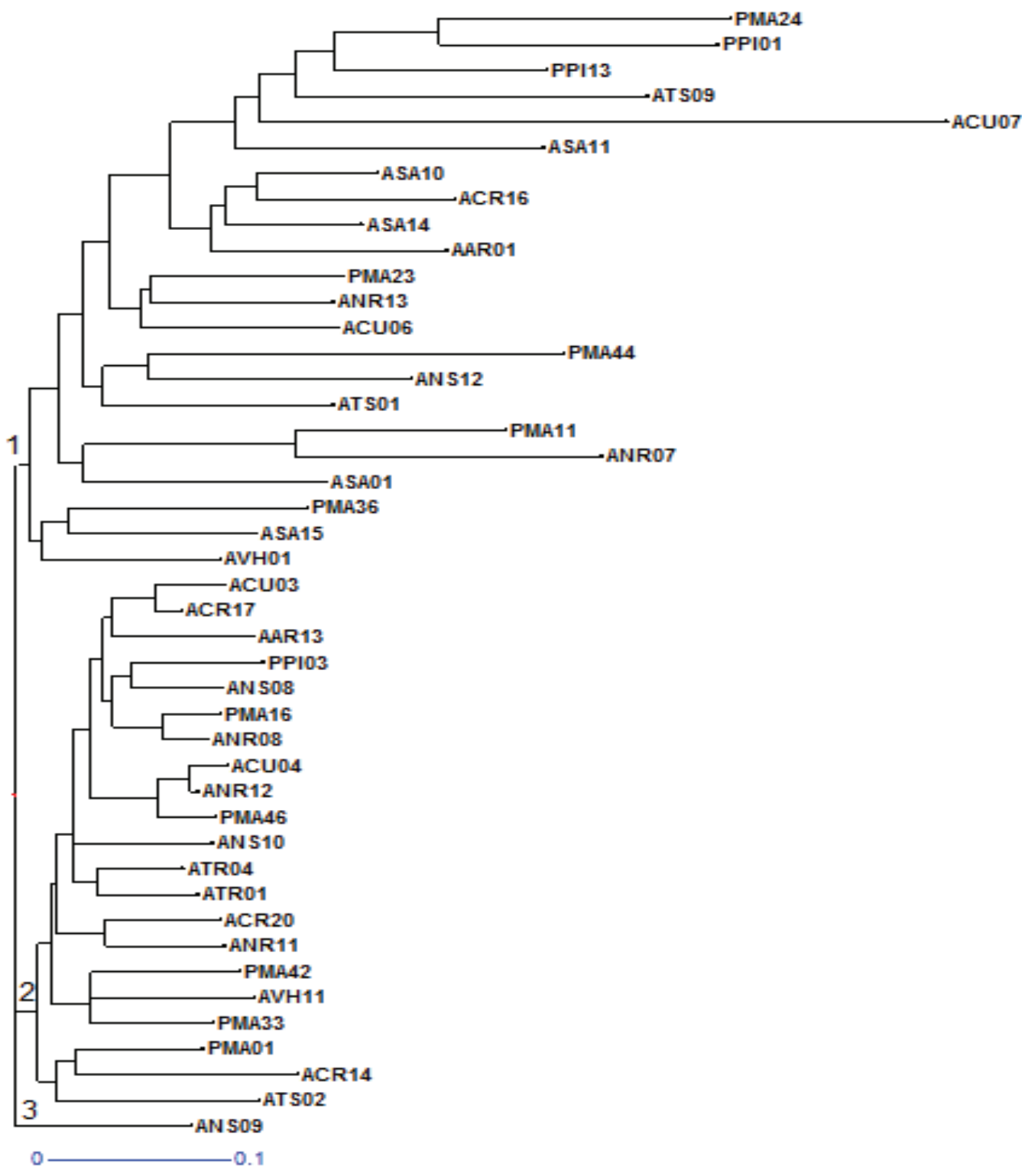

Figure 2. Dendrogram of 44 Guazuma crinita genotypes based on Jaccard's dissimilarity index.

Dendrograma de 44 genotipos de Guazuma crinita basado en el índice de disimiliridad de Jaccard.

et al. 2005, Dawson et al. 2008) in order to characterize levels of genetic variability and population structure.

A provenance test and a provenance/progeny test of $G$. crinita were established in the Aguaytia watershed in the Peruvian Amazon Basin to investigate genetic variation in growth and wood density, correlations between growth and density and environmental differences among planting zones in the watershed (Rochon et al. 2007, Weber and Sotelo-Montes 2008, Weber et al. 2011). Results from the provenance test indicated that the provenance from the local watershed (Aguaytia) performed better in terms of growth than did provenances from other watersheds in the Peruvian Amazon Basin (Weber and Sotelo-Montes 2008).
Rochon et al. (2007) observed significant genetic variation in tree growth at 12 months of age. Wood density also varied genetically among provenances (Weber and SoteloMontes 2008).

In this study of 44 genotypes from 11 provenances of G. crinita in two watersheds in the Peruvian Amazon, we characterized genetic diversity within the species at the molecular level using 10 ISSR markers. Although we were aware that our sample size was not extensive (limitation caused by small number of individual trees in the clonal orchard), other researchers have investigated genetic diversity in tree species using even smaller sample sizes (e.g. Hernández et al. 2006, Thangjam 2014). 
Our study revealed $93.8 \%$ polymorphic loci. Levels of genetic diversity within provenances estimated by Nei's gene diversity and Shannon's information index $(\mathrm{He}=0.03$ to $0.24 ; I=0.04$ to 0.35 ) were similar to those reported by other researchers for other tropical tree species. For example, Russell et al. (1999) used amplified fragment length polymorphism (AFLP) markers to analyze genetic diversity in provenances of Calycophyllum spruceanum Benth., which has a similar distribution pattern to that of $G$. crinita in the Peruvian Amazon, and reported that $\mathrm{He}$ ranged from 0.26 to 0.35 . Gillies et al. (1997) used a random amplified polymorphic DNA (RAPD) analysis to study populations of Cedrela odorata L. in Costa Rica, and reported that within-population diversity levels $(I)$ ranged from 1.18 to 1.89. Hollingsworth et al. (2005) evaluated diversity of natural and cultivated stands of Inga edulis: He was 0.59 to 0.70 , which are higher than those reported for G. crinita in this study. However $\mathrm{He}$ of $\mathrm{G}$. crinita is moderately high for woody and perennial species based on the analyses of Loveless and Hamrick (1987), indicating the presence of several alleles at some loci and an equitable distribution of allelic frequencies at most loci.

Overall genetic differentiation $\left(\mathrm{G}_{s t}=0.03\right)$ and gene flow $(\mathrm{Nm}=12.9)$ indicate that $97 \%$ of genetic variability was due to differences within provenances, and the provenances were not subject to genetic isolation. The high value for gene flow reflects both pollen dispersal and seed dispersal. Seeds can be dispersed over long distances by wind, and also downstream by water, hence we expected little differentiation among provenances. This is similar to the case of C. spruceanum, which showed much higher genetic variability within than among populations in the Peruvian Amazon (Russell et al. 1999). These results are also consistent with results from provenance and provenance/ progeny tests of G. crinita, which showed considerable genetic variation in tree growth and wood density within provenances (Rochon et al. 2007, Weber and Sotelo-Montes 2008, Weber et al. 2011).

There was a weak positive relationship between geographic and genetic distances of the provenances. However, the cluster analysis did not reveal any clear geographical pattern among the genotypes from the different provenances. Cluster groups, contained genotypes from several different provenances. These results probably reflect the high gene flow in the sample region or limitation of the ISSR markers to reveal the existing variation among provenances.

Results suggest that the provenances (populations) of G. crinita in the sample region form a meta-population of slightly differentiated subpopulations that are not genetically isolated because of gene flow (Lowe et al. 2005, White et al. 2007). The dynamic of gene flow via rivers within and among watersheds in the Peruvian Amazon Ba$\sin$ (Janský2008) and forest fragmentation due to shifting cultivation could contribute to the formation of subpopulations (Dourojeanni 1987). A report of genetic differentia- tion of Swietenia macrophylla King. using microsatellites markers indicated a moderate, though significant, degree of differentiation among populations in the Brazilian Amazon $\left(\mathrm{F}_{s t}=0.097\right)$, presumably due to the larger sample region compared with the one used in our study (Lemes et al. 2003). Kelly et al. (2004) studied temporal and spatial genetic variation of Vitellaria paradoxa Gaertn. in Africa where little variation was found at microsatellite loci between sampled stands with no evidence for genetic bottleneck events in agroforests.

\section{CONCLUSIONS}

The ISSR primers used in this study of G. crinita genotypes from 11 provenances showed high levels of polymorphism even in our rather small sample size. Most diversity occurred within rather than among provenances. It seems that, there exists extensive gene flow, thus the provenances were not genetically isolated. There was no clear grouping of genotypes based on the genotypes' provenance of origin or proximity to other provenances. Nevertheless, there was a weak positive correlation between genetic and geographic distance of the provenances.

Our results confirm that even a small clonal garden that was used in our research --under the conditions that the collection be correctly done-- could possess relatively high genetic diversity and thus could form a good base for further domestication of the species. In addition to $e x$ situ clonal gardens, in situ conservation of populations of G. crinita with higher genetic diversity should be promoted to maintain a broad genetic base for future tree domestication programs. Since seeds are dispersed by rivers downstream, we might expect higher genetic diversity below the confluence of major rivers, consequently targeting conservation in these areas may be an effective conservation strategy.

This study indicates that ISSR markers are effective and a relatively easy way to detect polymorphism and characterization of genetic variation. However, we recommend analyzing more samples per population with employment of other types of molecular markers in future studies of genetic diversity as a basis of genetic improvement to G. crinita and also to include natural populations across other watersheds in further research.

\section{ACKNOWLEDGMENTS}

The authors thank Manuel Soudre for providing access to the clonal garden and information about the genotypes of G. crinita used in this research. The authors thank Joel Odicio for support with the molecular markers analyses. This research was supported financially by the Internal Grant Agency of Czech University of Life Science Prague CIGA (Project No. 20145005), the Internal Grant Agency of Faculty of Tropical Agri-Sciences, Czech University of Life Sciences Prague IGA (Project No. 20145023) and Universidad Nacional de Ucayali-Peru. 


\section{REFERENCES}

Dawson IK, P Hollingsworth, JJ Doyle, S Kresovich, JC Weber, S Sotelo-Montes, TD Pennington, RT Pennington. 2008. Tree origins and conservation on farm: a case study from the Peruvian Amazon. Conservation Genetics 9: 361-372.

Dourojeanni R. 1987. Aprovechamiento del barbecho forestal en áreas de agricultura migratoria en la Amazonía Peruana. Revista Forestal del Perú 14: 15-61.

Doyle JJ, JL Doyle. 1987. A rapid DNA isolation procedure for small quantities of fresh tissue. Phytochemical Bulletin 19: 11-15.

Encarnación F. 1983. Nomenclatura de las especies forestales comunes en el Perú. Proyecto PNUD.FAO.PER 81/002 Fortalecimiento de los programas de desarrollo forestal en la Selva Central. Lima, Perú. Ministerio de Agricultura, Instituto Nacional Forestal y de Fauna. 149 p. (Documento de trabajo No. 7)

Gillies ACM, J Cornelius, AC Newton, C Navarro, M Hernandez, J Willson. 1997. Genetic variation in Costa Rica populations of the tropical timber species Cedrela odorata L., assessed using RAPDs. Molecular Ecology 6:1133-1145.

Hernández CAR, LA Kafuri, RA Isaza, MI Arias. 2006. Analysis of genetic variation in clones of rubber (Hevea brasiliensis) from Asian, South and Central American origin using RAPDs markers. Revista Colombiana de Biotecnología 8:29-34.

Hollingsworth P, I Dawson, W Goodall-Copestake, J Richardson, JC Weber, C Sotelo-Montes, T Pennington. 2005. Do farmers reduce genetic diversity when they domesticate tropical trees? A case study from Amazonia. Molecular Ecology 14:497-501.

IIAP (Instituto de Investigación de la Amazonía Peruana, PE). 2009. Evaluación económica de parcelas de regeneración natural y plantaciones de bolaina blanca, Guazuma crinita, en el departamento de Ucayali. Loreto, Perú. IIAP. 54 p. (Avance Económico Nº11).

Janský B. 2008. La región de los orígenes del Amazonas. In Janský B, J Česák, D Duran Castro, Z Engel, J Kastner, J Kořinek, I Kupčik, A Lajo, S Nuñez Juares, C Peñaherrera Del Aguila, L Šefrna eds. Los orígenes del Amazonas. Praha, Cezch Republic. Otto. p. 151-214.

Kelly BA, OJ Hardy, JM Bouver. 2004. Temporal and spatial genetic structure in Vitellaria paradoxa (shea tree) in an agroforestry system in southern Mali. Molecular Ecology 13:1231-1240.

Labarta RA, JC Weber. 1998.Valorización económica de bienes tangibles de cinco especies arbóreas agroforestales en la Cuenca Amazónica Peruana. Revista Forestal Centroamericana 23: 12-21.

Leakey RRB, JC Weber, T Page, JP Cornelius, FK Akinnifesi, JM Roshetko, Z Tchound-Jeu, R Jamnadass.2012. Tree domesticationin agroforestry: Progress in the second decade (2003-2012). In PKR Nair, D Garrity eds. Agroforestry the future of global land use. Advances in Agroforestry 9 (2): $145-173$.

Lemes MR, R Gribel, J Procor, D Grattapaglia. 2003. Popula- tion genetic structure of mahogany (Swietenia macrophylla King, Meliaceae) across the Brazilian Amazon, base on microsatellite at the loci: Implication for conservation. Molecular Ecology 12: 2875-2883.

Loveless MD, JL Hamrick. 1987. Distribución de la variación en especies de árboles tropicales. Revista de Biología Tropical 35 (1) $165-175$.

Lowe A, D Boshier, M Ward, C Bacles, C Navarro.2005. Genetic resource impacts of habitat loss and degradation; reconciling empirical evidence and predicated theory for neotropical trees. Heredity 95:255-273.

Muchugi A, C Kadu, R Kindt, H Kipruto, S Lemurt, K Olale, P Nyadoi, I Dawson, R Jamnadass. 2008. Molecular Markers for Tropical Trees, A Practical Guide to Principles and Procedures. In Dawson I, R Jamnadass eds. Nairobi, Kenia. World Agroforestry Centre. 100 p. (Technical Manual № 9).

O’Neill G, I Dawson, C Sotelo-Montes, L Guarino, M Guariguata, D Current, JC Weber. 2010. Strategies for genetic conservation of trees in the Peruvian Amazon. Biodiversity and Conservation 10: 837-850.

Perrier X, JP Jacquemoud-Collet. 2006. Darwin software. Consulted 15 May 2014. Available at http://darwin.cirad.fr/ darwin

Peakall R, PE Smouse. 2012. GenAlEx 6.5: genetic analysis in Excel. Population genetic software for teaching and research-an update. Bioinformatics 28: 2537-2539.

Rochon C, HA Margolis, JC Weber.2007. Genetic variation in growth of Guazuma crinita (Mart.) trees at an early age in the Peruvian Amazon. Forest Ecology and Management 243:291-298.

Russell JR, JC Weber, A Booth, W Powell, C Sotelo-Montes, IK Dawson. 1999. Genetic variation of Calycophyllum spruceanum in the Peruvian Amazon basin, revealed by AFLP analysis. Molecular Ecology 8: 199-204.

Sotelo-Montes C, JC Weber. 1997. Priorización de especies arbóreas para sistemas agroforestales en la selva baja del Perú. Agroforestería de las Américas 4: 12-17.

Thangjam R. 2014.Inter-Simple Sequence Repeat (ISSR) Marker Analysis in Parkia timoriana (DC.) Merr. Populations from Northeast India. Applied Biochemistry and Biotechnology 172: 1727-1734.

Weber JC, C Sotelo-Montes. 2008. Geographic variation in tree growth and wood density of Guazuma crinita Mart. in the Peruvian Amazon. New Forest 36:29-52.

Weber JC, C Sotelo-Montes, J Cornelius, J Ugarte.2011. Genetic variation in tree growth, stem form and mortality of Guazuma crinita in slower- and faster-growing plantations in the Peruvian Amazon. Silvae Genetica30: 70-78.

White TL, WT Adams, DB Neale. 2007. Within population variation, genetic diversity, mating systems and stand structures. In CABI Publishing eds. Forest Genetics. Cambridge, United Kingdom. p. 149-283.

Yeh FC, RC Yang, TB Boyle, ZH Ye, JX Mao. 1997. POPGENE ver. 1.32 the user-friendly shareware for population genetic analysis. Molecular Biology and Biotechnology Center, University of Alberta. Canada (program available in: http:// www.ualberta.ca/ fyeh/). 